\title{
$\beta$-Catenin Expression and Activation in Conjunctival Melanoma
}

\author{
Emerentienne Larivéa ${ }^{a}$ Michael Nicolas ${ }^{c}$ Gürkan Kaya ${ }^{d}$ Nicolo Riggi ${ }^{b}$ \\ Alexandre P. Moulin ${ }^{c}$ \\ aLausanne University, Lausanne, Switzerland; ${ }^{b}$ Experimental Pathology, Lausanne University \\ Pathology Institute, Lausanne, Switzerland; ' Jules-Gonin Eye Hospital, Lausanne University, \\ FAA, Lausanne, Switzerland; d Dermatopathology Unit, Department of Dermatology, \\ University Hospital of Geneva, Geneva, Switzerland
}

Keywords

Eye $\cdot$ Melanogenesis $\cdot$ Melanoma $\cdot$ Conjunctiva

\begin{abstract}
Purpose: To assess the role of the canonical Wnt pathway via activation of $\beta$-catenin in tumor progression of conjunctival melanoma. Methods: $\beta$-Catenin localization was assessed by immunohistochemistry in 43 conjunctival nevi, 48 primary acquired melanoses (PAM; conjunctival melanocytic intraepithelial neoplasia), and 44 conjunctival melanomas. Activation of the canonical or the noncanonical Wnt pathway was tested in vitro in 4 conjunctival melanoma cell lines with stimulation of either Wnt5a or Wnt3a. Wound healing assays were performed with Wnt5a. Results: Nuclear $\beta$-catenin expression was found in $16 \%$ of the nevi, in $15 \%$ of the melanomas, and in $4 \%$ of the PAM. Membranous $\beta$-catenin expression was identified in all the nevi and PAM and in $97.7 \%$ of the melanomas. In vitro, Wnt5a stimulation in the 4 conjunctival melanomas and in 1 skin melanoma cell line did not induce nuclear translocation of $\beta$-catenin, nor did it increase cell motility in the wound healing assays. Wnt3a stimulation did not induce nuclear localization of $\beta$-catenin in any of the cell lines tested. Conclusions: In conjunctival melanoma, nuclear localization and activation of $\beta$-catenin appear to be limited, suggesting that inhibition of ARF6, responsible for $\beta$-catenin activation, in subsets of skin melanoma may not represent a treatment option for this tumor. In vitro, Wnt3a or Wnt5a did not induce nuclear $\beta$-catenin localization.


Larivé et al.: $\beta$-Catenin in Conjunctival Melanoma

\section{Introduction}

Conjunctival melanoma (CM) is a rare but life-threatening disease. In 2005, the incidence was estimated at 0.4 per 1 million in the USA [1]. A prospective Swedish study demonstrated a dramatic increase in the incidence of CM during the period of 1960-2005 from 0.08 to 0.56 cases per 1 million [2]. CM occurs almost exclusively among Caucasian populations; fewer than 1\% arise in African-American patients [1]. A correlation between ultraviolet light exposure and CM was established by Rivolta et al. [3] in 2016.

The majority of CM arise from preexisting atypical intraepithelial melanocytic proliferations (primary acquired melanosis [PAM] with atypia) [4], also recently called conjunctival intraepithelial melanocytic neoplasia [5]. CM also develops from conjunctival nevi or, less frequently, de novo.

Recent evidence suggests that cutaneous melanomas and CM have similar molecular features, notably similar mutations in driver genes such as BRAF, NRAS, and $N F 1$ [6, 7]. We have previously demonstrated that this genetic background leads, in $\mathrm{CM}$, to an increased activation of the MAPK pathway, and possibly also of the PI3K/mTOR pathway. In skin melanoma, another pathway - the Wnt pathway - has been extensively evaluated $[8,9]$. This tightly regulated pathway appears critical for melanocytic differentiation [10], transformation [9], escape from senescence [10,11], cellular proliferation [9], migration, and invasiveness, as well as for metastasis.

The Wnt pathway is complex and signals through several G protein-coupled protein receptors (Frizzled) as well as several coreceptors (ROR1, ROR2, LRP5/6, and RYK). In the canonical Wnt pathway, the presence of specific Wnt ligands, notably Wnt1 and Wnt3a, leads to cytoplasmic accumulation of $\beta$-catenin through preservation from proteasomal degradation [31]. $\beta$-Catenin further translocates into the nucleus, where it serves as a coactivator for the transcription of Wnt target genes [31]. Alternatively, in the noncanonical Wnt pathway, the signaling, mediated notably by Wnt5a, leads to an increased cytoplasmic release of calcium from endoplasmic reticulum and protein kinase $\mathrm{C}$ activation. In cutaneous melanoma, Wnt5a-mediated protein kinase $C$ activation increases cell motility $[12,13]$ and invasiveness [14], reduces proliferation, and has been associated with the downregulation of tumor suppressor (Kiss1) [12]. In skin melanoma, the interaction with various ligands will either activate the canonical or the noncanonical Wnt pathway. It has been hypothesized that canonical Wnt pathway activation, notably via $\beta$-catenin-mediated control of MITF [15], occurs early in tumor development [8]. $\beta$-Catenin increases proliferation by upregulating Brn-2 [16] and allows escape from senescence by p16 downregulation [17]. On the other hand, the noncanonical Wnt pathway might be implicated later in tumor development and in metastasis.

Recently, a role for Wnt5a in stimulation of the Wnt canonical pathway was found: through the activation of ARF6, Wnt5a stimulated the release of $\beta$-catenin from $\mathrm{N}$-cadherin, converting junctional $\beta$-catenin into cytoplasmic pools available for nuclear translocation [11]. In specific melanoma cell lines, $\beta$-catenin activation and nuclear localization were associated with an increased invasiveness. ARF6 inhibition reduced nuclear pools of $\beta$-catenin, and cells lost their invasive capacity [18]. These data suggest that inhibition of ARF6 may be a way to inhibit the Wnt/ $\beta$-catenin pathway in melanoma. On the other hand, in vivo data demonstrated no nuclear expression of $\beta$-catenin in primary and metastatic cutaneous melanoma [19].

As, to the best of our knowledge, the Wnt pathway has not been evaluated in CM, we here investigated $\beta$-catenin expression and activation in benign and malignant conjunctival melanocytic proliferations. We also assessed in vitro $\beta$-catenin activation through Wnt5a or Wnt3a stimulation, as well as the Wnt5a effect on migration. 


\section{Materials and Methods}

\section{Tissue and Case Selection}

Tissue samples were obtained from patients treated at the Jules-Gonin Eye Hospital (Lausanne, Switzerland). The study included CM samples that had been archived between 1998 and 2016. The study samples consisted of 43 cases of benign conjunctival nevus (1 junctional nevus, 21 compound nevi, and 21 subepithelial nevi), 48 cases of PAM (25 without atypia and 23 with atypia), and 44 cases of CM.

\section{Clinicopathological Variables}

Patient data regarding age at diagnosis, sex, tumor localization, recurrence, metastasis, mortality, and possible precursor lesions (nevi or PAM) were retrieved from the Jules-Gonin Eye Hospital's clinical files.

The following histopathologic elements were also recorded: diagnosis, mitotic activity, depth of invasion, lymphatic invasion, and genetic mutational profile (BRAF and NRAS), if available, as well as TNM stage.

\section{Immunohistochemistry}

Formalin-fixed paraffin-embedded tissues were retrieved from the archives of the JulesGonin Eye Hospital Pathology Laboratory. Sections $5 \mu \mathrm{m}$ in size were cut and hematoxylineosin stains were performed. The sections were incubated with $\beta$-catenin antibody (clone $14 / \beta$-catenin, Mouse monoclonal, dilution 1:800; BD Biosciences). A streptavidin/biotin detection method with 3-amino-9-ethylcarbazole was used for signal detection (Dako EnVision System/HRP Dual Link). Skin melanoma, colon, and tonsil tissues were included as positive controls. Matched negative isotype controls were also performed.

Two observers (E.L. and A.M.) reviewed and independently scored the immunohistochemistry results. For each sample, membranous, cytoplasmic, and nuclear staining was assessed. For each cell localization, we enumerated the proportion of stained cells using a 1-3 scale $(1=$ positive staining in $<10 \%$ of the cells; $2=$ positive staining in $10-50 \%$ of the cells; $3=$ positive staining in $>50 \%$ of the cells). A score of 1 was interpreted as negative, and scores of 2 and 3 as positive. When independent scoring for positively stained cells differed, the slides were reviewed to reach mutual agreement.

\section{Cell Lines}

Four CM cell lines were used: T1527A, which has been established at our institution with $B R A F^{G 466 E}$ and HRAS ${ }^{Q 61 R}$ mutations; CM2005.1 and CRMM1, both with BRAF ${ }^{V 600 E}$ mutations; and CRMM2 with an NRAS ${ }^{Q 61 L}$ mutation. A cutaneous melanoma cell line (SKMEL-37) was also used as a control.

\section{$\beta$-Catenin Activation}

CM2005.1, CRMM1, and CRMM2 were cultured in F-12K nutrient mixture, Kaighn's modification, containing L-glutamine (Gibco, Life Technologies), 10\% heat-inactivated FBS (Greiner Bio-One, The Netherlands), and 2\% penicillin/streptomycin (Gibco). T1527A was established at our laboratories (Jules-Gonin Eye Hospital and Ludwig Center for Cancer Research, Switzerland) from a perilimbic CM extending onto the cornea of a 65-year-old man. These cells were grown in a mixture of 50\% of RPMI 1640-modified medium (Gibco) and 50\% DMEM/ F-12 (Dulbecco's modified Eagle medium/Nutrient Mixture F-12 with GlutaMAX ${ }^{\mathrm{TM}}$; Gibco) supplemented with 10\%FBS(GreinerBio-One)and6mM HEPES(N-2-hydroxyethylpiperazine$\mathrm{N}^{\prime}$-2-ethanesulfonic acid; Gibco). The different cell lines were treated with $100 \mathrm{ng} / \mu \mathrm{L}$ of ligand Wnt3a or Wnt5a for $48 \mathrm{~h}$ in their respective medium. At the end of treatment, each cell 
Table 1. Clinical characteristics of conjunctival melanocytic proliferation samples evaluated

\begin{tabular}{|c|c|c|c|c|c|c|}
\hline \multirow{2}{*}{$\begin{array}{l}\text { Melanocytic } \\
\text { tumor type }\end{array}$} & \multirow{2}{*}{$\begin{array}{l}\text { Total, } \\
n\end{array}$} & \multicolumn{2}{|c|}{ Gender } & \multirow{2}{*}{$\begin{array}{l}\text { Median age } \\
\text { (SD), years }\end{array}$} & \multirow{2}{*}{$\begin{array}{l}\text { Melanocytic tumor } \\
\text { subtype }\end{array}$} & \multirow[t]{2}{*}{$n$} \\
\hline & & male & female & & & \\
\hline \multirow[t]{3}{*}{ Nevi } & 43 & 23 & 20 & 42.95 (2.88) & Compound nevus & 21 \\
\hline & & & & & Junctional nevus & 1 \\
\hline & & & & & Subepithelial nevus & 21 \\
\hline \multirow[t]{2}{*}{ PAM } & 48 & 20 & 28 & $58.73(2.76)$ & Without atypia & $25(52 \%)$ \\
\hline & & & & & With atypia & $23(48 \%)$ \\
\hline \multirow[t]{3}{*}{$\mathrm{CM}$} & 44 & 17 & 27 & $65.7(2.63)$ & De novo & $9(20.5 \%)$ \\
\hline & & & & & Preexisting nevus & $7(15.9 \%)$ \\
\hline & & & & & Preexisting PAM & $28(63.6 \%)$ \\
\hline
\end{tabular}

PAM, primary acquired melanosis; CM, conjunctival melanoma.

line was washed 3 times with PBS and fixed with formol followed by immunofluorescence staining with $\beta$-catenin antibody (clone 14/ $\beta$-catenin, Mouse monoclonal, dilution 1:200; BD Biosciences) and with Alexa Fluor goat anti-mouse antibody (dilution 1:2,000).

\section{Wound Healing Assays}

For each cell line, cells were seeded in 12 different wells with serum $10 \%$. The experiment was realized with two different cell concentrations (high concentration: $3 \times 10^{5}$; low concentration: $0.75 \times 10^{5}$ ). The cells were allowed to grow until confluence for 2-4 days.

When the cells were confluent, the wells were washed out with PBS, and RPMI $1640+$ $0.5 \%$ serum was added. As serum starvation minimizes proliferation but complete starvation may induce cell death, we maintained a reduced concentration of serum [20]. Six hours later, the cell monolayer was scratched with a pipette tip. The wells were washed with PBS, and medium $+0.5 \%$ serum was added. Half of the wells were treated with Wnt5a or Wnt3a (target concentration: $100 \mathrm{ng} / \mathrm{mL}$ ). The cells were maintained in culture, and their migration was followed at different time points $(0,24,48$, and $72 \mathrm{~h})$ until wound closure. Images were recorded using a $100 \times$ magnification microscope. For each frame, when wound closure was reached in one well, it was compared to the level of healing in the other wells. Immunohistochemistry was also realized on these cell lines with and without Wnt5a or Wnt3a.

\section{Statistics}

Statistical analysis was performed using JMP 8.0 software. Tests of significance were two-tailed, and results were considered significant at an $\alpha$ level of $p<0.05 . \chi^{2}$ tests were used to establish differences in distribution of the discontinuous variables. Student's $t$ test or one-way ANOVA were used for continuous variables with a normal distribution, and MannWhitney U/ Kruskal-Wallis tests were used to compare continuous variables without a normal distribution.

\section{Results}

\section{Clinicopathological Cohort}

Our study included samples from 44 patients diagnosed with CM, 48 patients with PAM, and 43 patients with conjunctival nevi (Table 1 ). These groups did not differ by gender ( $p=$ 


\begin{tabular}{|l|c|c|}
\hline Nevi, $n=43$ & $\beta$-Catenin Mb. & $\beta$-Catenin N. \\
\hline Score $1 \square$ & 0 & $37(84 \%)$ \\
\hline Score 2 & $10(23.2 \%)$ & $6(16 \%)$ \\
\hline Score 3 $\square$ & $33(76.8 \%)$ & 0 \\
\hline Melanomas, $n=44$ & & $37(84 \%)$ \\
\hline Score 1 & $1(2.3 \%)$ & $5(11.5 \%)$ \\
\hline Score 2 $\square$ & $13(29.5 \%)$ & $2(4.5 \%)$ \\
\hline Score 3 $\square$ & $30(68.2 \%)$ & \\
\hline PAM, $n=48$ & & $45(95.8 \%)$ \\
\hline Score 1 $\square$ & 0 & $2(4.2 \%)$ \\
\hline Score 2 & $1(2.1 \%)$ & 0 \\
\hline Score 3 & $47(97.9 \%)$ & \\
\hline
\end{tabular}

$\beta$-Catenin $\mathrm{Mb}$.
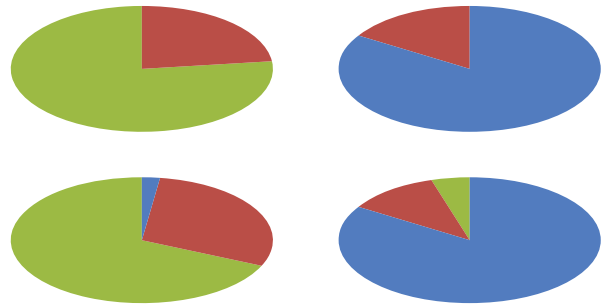

Melanomas
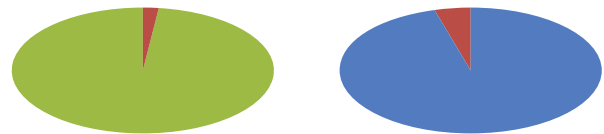

PAM

Fig. 1. $\beta$-Catenin expression in conjunctival melanocytic proliferations. PAM, primary acquired melanosis.

Table 2. Clinicopathological correlations: $\beta$-catenin expression in CM

\begin{tabular}{|c|c|c|c|c|c|c|}
\hline & $\begin{array}{l}\text { Nuclear } \\
\beta \text {-catenin present }\end{array}$ & $\begin{array}{l}\text { Nuclear } \\
\beta \text {-catenin absent }\end{array}$ & $p$ & $\begin{array}{l}\text { Membranous } \\
\beta \text {-catenin present }\end{array}$ & $\begin{array}{l}\text { Membranous } \\
\beta \text {-catenin absent }\end{array}$ & $p$ \\
\hline Age & & & 0.680 & & & 0.312 \\
\hline$<65$ years & 3 & 19 & & 21 & 1 & \\
\hline$>65$ years & 4 & 18 & & 22 & 0 & \\
\hline Sex & & & 0.551 & & & 0.422 \\
\hline Male & 2 & 15 & & 17 & 0 & \\
\hline Female & 5 & 22 & & 26 & 1 & \\
\hline Localization & & & 0.933 & & & 0.536 \\
\hline Bulbar & 5 & 27 & & 31 & 1 & \\
\hline Nonbulbar & 2 & 10 & & 12 & 0 & \\
\hline Depth of invasion & & & 0.659 & & & 0.608 \\
\hline$>0.5 \mathrm{~mm}$ & 6 & 29 & & 34 & 1 & \\
\hline$<0.5 \mathrm{~mm}$ & 1 & 8 & & 9 & 0 & \\
\hline Ki-67 index & 19.00 & 22.583 & 0.489 & 21.81 & 30.00 & 0.519 \\
\hline Local lymphatic invasior & & & 0.234 & & & 0.080 \\
\hline Yes & 3 & 8 & & 10 & 1 & \\
\hline No & 4 & 29 & & 33 & 0 & \\
\hline TNM stage & & & 0.243 & & & 0.176 \\
\hline $\mathrm{T} 1$ & 4 & 23 & & 27 & 0 & \\
\hline $\mathrm{T} 2$ & 0 & 7 & & 7 & 0 & \\
\hline T3 & 3 & 7 & & 9 & 1 & \\
\hline Recurrences & & & 0.913 & & & 0.398 \\
\hline Yes & 4 & 19 & & 22 & 1 & \\
\hline No & 3 & 13 & & 16 & 0 & \\
\hline \multicolumn{7}{|l|}{ Origin } \\
\hline Nevus & 0 & 7 & 0.209 & 7 & 0 & 0.660 \\
\hline PAM & 4 & 24 & 0.697 & 28 & 0 & 0.181 \\
\hline De novo & 3 & 6 & 0.109 & 8 & 1 & 0.046 \\
\hline Death & & & 0.805 & & & 0.688 \\
\hline Yes & 1 & 4 & & 5 & 0 & \\
\hline No & 5 & 27 & & 31 & 1 & \\
\hline
\end{tabular}

CM, conjunctival melanoma; PAM, primary acquired melanosis. 

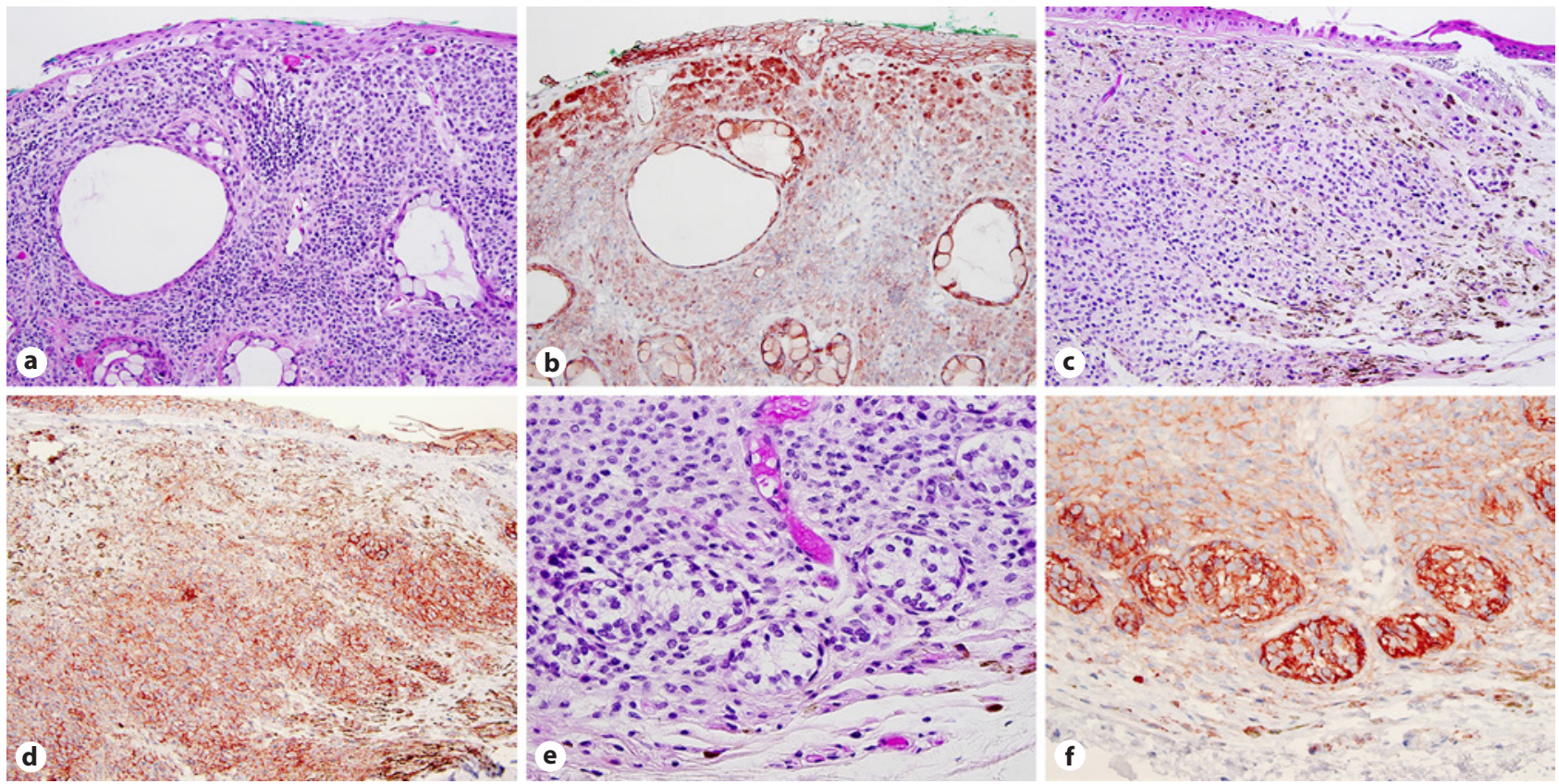

Fig. 2. $\beta$-Catenin expression in conjunctival nevi. a Compound nevus. H\&E. $\times 126$. b Membranous $\beta$-catenin is expressed in the entire nevus. Some nevus cells also demonstrate nuclear expression. $\times 126$. c H\&E. $\times 126$. d Membranous $\beta$-catenin is expressed in the entire nevus. $\times 126$. e H\&E. $\times 252$. $\mathbf{f}$ In some nests in the deep component of the nevus containing cells with a larger and clearer cytoplasm, stronger cytoplasmic expression can be identified. $\times 252$.

0.373), but a significant difference in age was observed between the patients with nevi and the patients with CM $(p<0.0001)$, as well as between the patients with PAM and the patients with $\mathrm{CM}(p=0.0354)$.

In all, 32 melanomas were arising in the bulbar conjunctiva, and 12 in the nonbulbar conjunctiva. Twenty-seven tumors belonged to the T1 tumor category, 7 to the T2 category, and 10 to the T3 category. Seven melanomas arose from a nevus, 28 from PAM, and 9 de novo. The overall follow-up was $60.7 \pm 9.3$ months. Seven patients had developed metastasis and 5 patients had died of the tumor. Recurrences were found in $59 \%$ of the cases.

\section{Immunohistochemical Analysis}

The results for $\beta$-catenin expression are summarized in Figure 1. The clinicopathological correlations are summarized in Table 2 . $\beta$-Catenin expression in nevi is illustrated in Figure 2 , that in PAM in Figure 3, and that in melanomas in Figure 4.

\section{Nuclear $\beta$-Catenin}

Nuclear $\beta$-catenin expression was found in only $16 \%$ of the nevi, $15 \%$ of the melanomas, and $4 \%$ of the PAM. There was no significant difference in expression between CM and nevi and PAM ( $p=0.1556)$.

In the $\mathrm{CM}$, there was no significant correlation of depth of invasion with nuclear $\beta$-catenin expression (Kruskal-Wallis test, $p=0.1967$ ), nor with the proliferation index Ki-67 (KruskalWallis test, $p=0.1135$ ). No correlation could be identified between nuclear $\beta$-catenin expression and tumor localization, local lymphaticinvasion, TNM score, recurrence, melanoma origin (PAM, nevus, or de novo), death, and metastasis. 

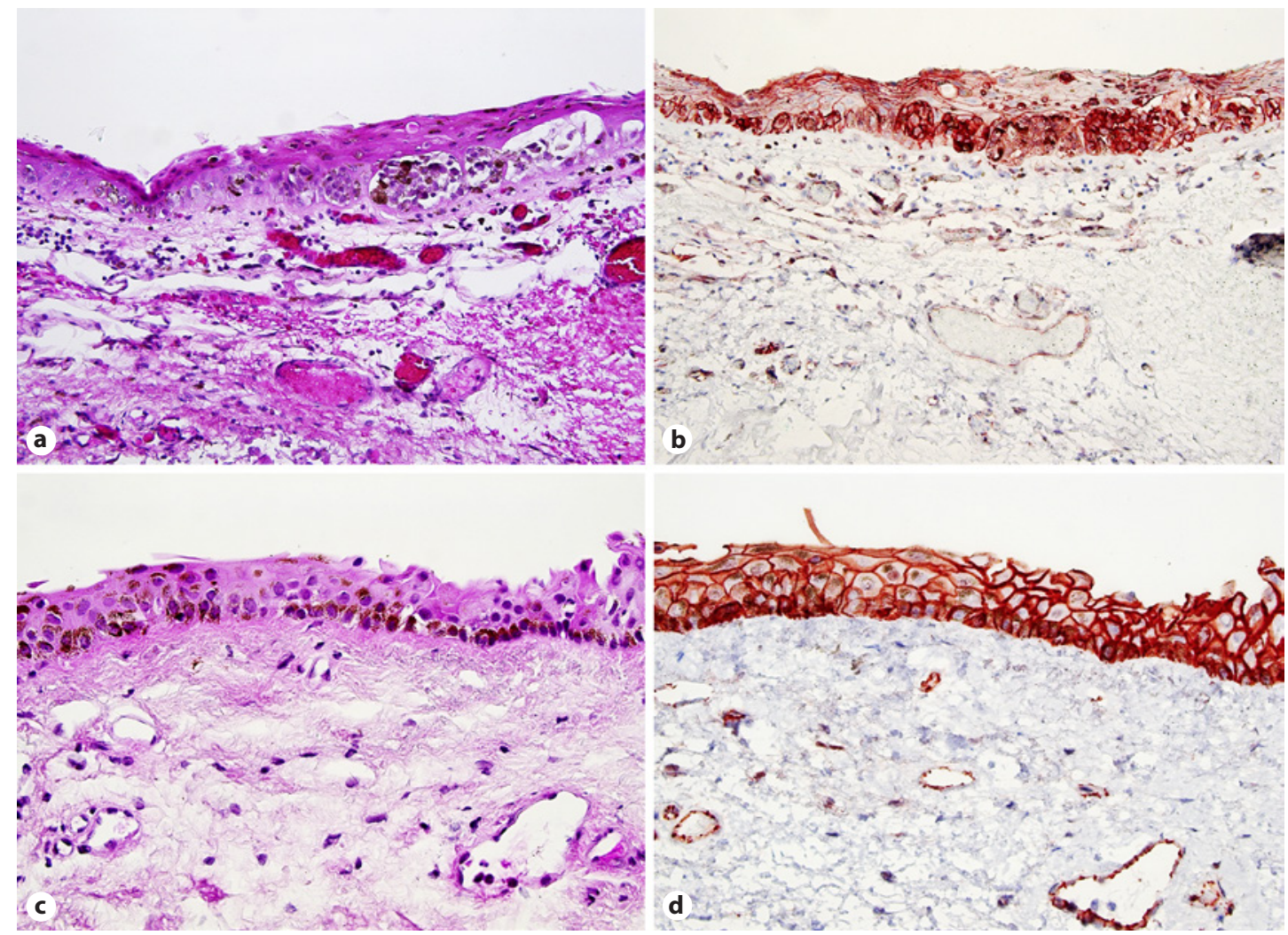

Fig. 3. $\beta$-Catenin expression in PAM. a PAM with atypia (conjunctival melanocytic intraepithelial neoplasia score 5). H\&E. $\times 126$. b $\beta$-Catenin expression is mainly membranous. $\times 126$. c PAM without atypia. H\&E. $\times 252$. d $\beta$-Catenin expression is mainly membranous. $\times 252$. PAM, primary acquired melanosis.

\section{Membranous $\beta$-Catenin}

Membranous $\beta$-catenin was found in all the nevi and PAM, as well as in $97.7 \%$ of the CM $(97.7 \%)(p=0.0037)$. Membranous $\beta$-catenin was associated with death (Pearson, $p=0.0301)$, but not with any other variable of this study.

\section{In vitro $\beta$-Catenin Assessment}

The State of Confluence Does Not Induce Nuclear $\beta$-Catenin Localization

We initially assessed in the four CM cell lines whether nuclear $\beta$-catenin localization was correlated with the state of confluence (online suppl. Fig. 1; for all online suppl. material, see www.karger.com/doi/10.1159/000500682). $\beta$-Catenin was mainly localized on the cell membrane, regardless of the state of confluence.

Wnt5a Stimulation of the Noncanonical Wnt Pathway Does Not Induce Nuclear

$\beta$-Catenin Relocalization

Since in subsets of cutaneous melanoma cell lines, Wnt5a increases $\beta$-catenin signaling, we decided to test the effect of Wnt5a stimulation on $\beta$-catenin in CM cell lines. Wnt5a stimulation did not lead to nuclear $\beta$-catenin translocation in any of the cell lines evaluated (Fig. 5). 


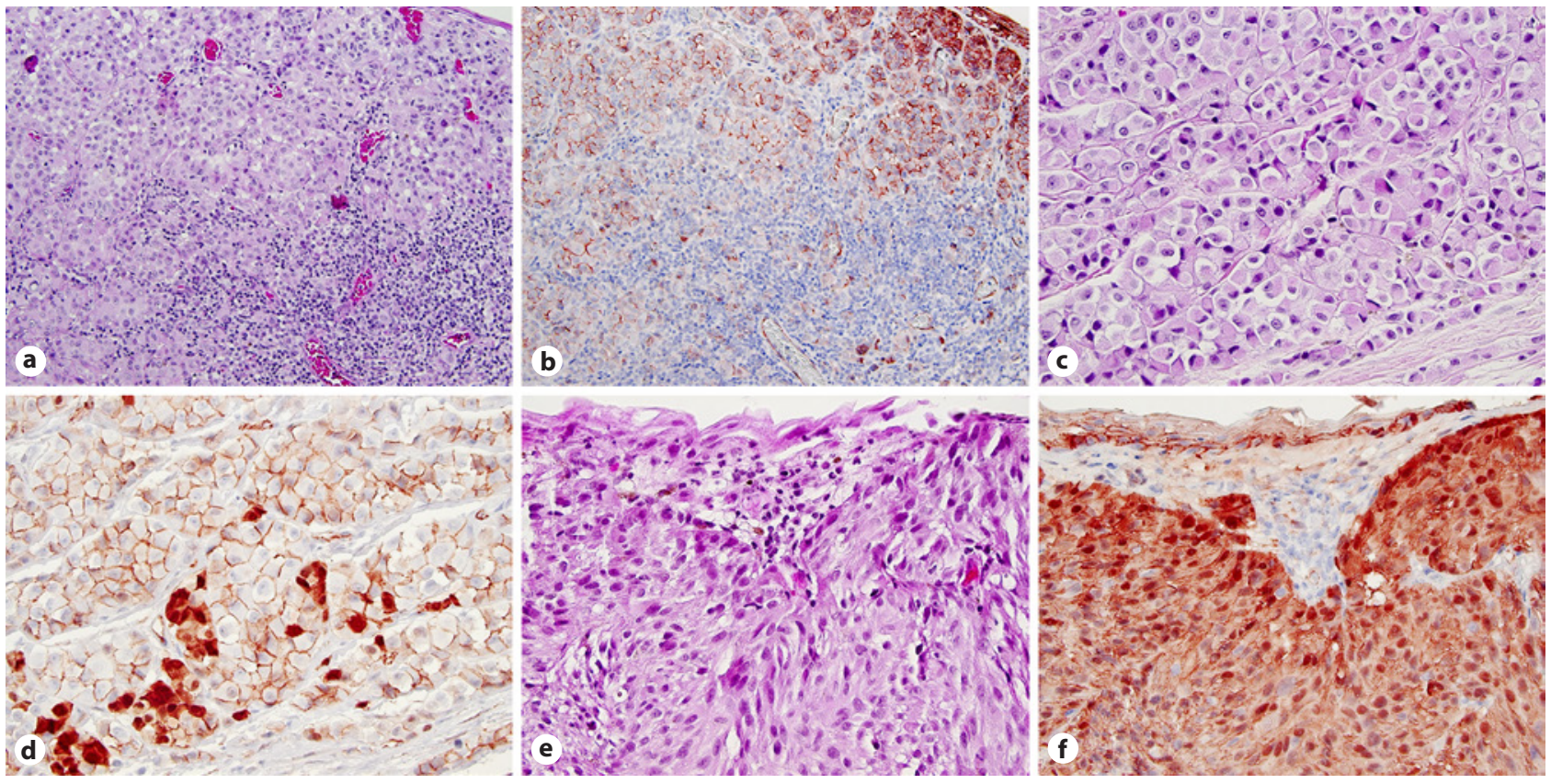

Fig. 4. $\beta$-Catenin expression in conjunctival melanoma. a Vertical-growth-phase melanoma. H\&E. $\times 126$. b There is diffuse membranous $\beta$-catenin expression. $\times 126$. c Melanoma composed of large epithelioid cells. H\&E. $\times 252$. d While there is diffuse membranous $\beta$-catenin expression, nuclear and cytoplasmic $\beta$-catenin expression can be found in some cells. H\&E. $\times 252$. e Mixed-cell-type melanoma. H\&E. $\times 252$. f Nuclear and cytoplasmic $\beta$-catenin expression. $\times 252$.

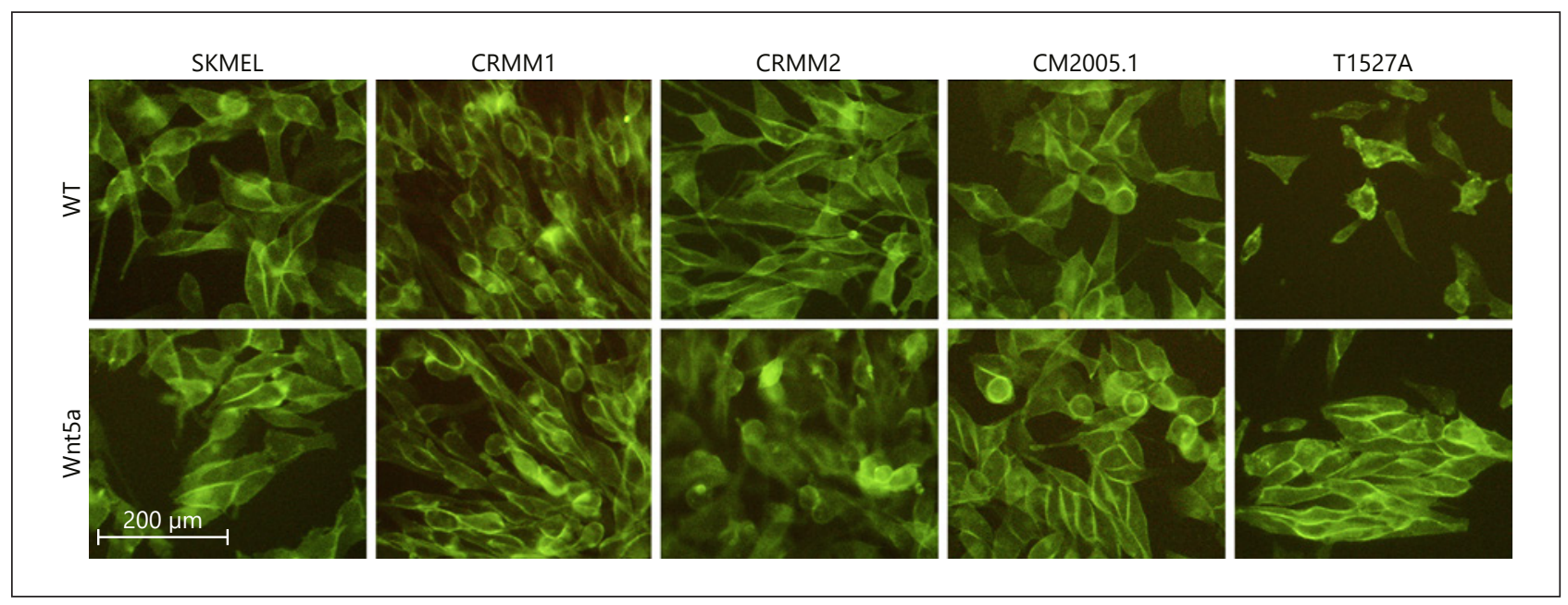

Fig. 5. Wnt5a did not induce nuclear localization of $\beta$-catenin. In the untreated (WT) conjunctival melanoma cell lines and in one skin melanoma cell line (SKMEL), $\beta$-catenin was localized at the cell membrane. Incubation with Wnt5a did not lead to nuclear $\beta$-catenin localization.

Stimulation of the Canonical Wnt Pathway with Wnt3a Ligand Does Not Induce Nuclear $\beta$-Catenin Relocalization

We next decided to test whether stimulation of the canonical Wnt pathway with Wnt3a would induce the activation of $\beta$-catenin and nuclear expression. Surprisingly, in all the cell 


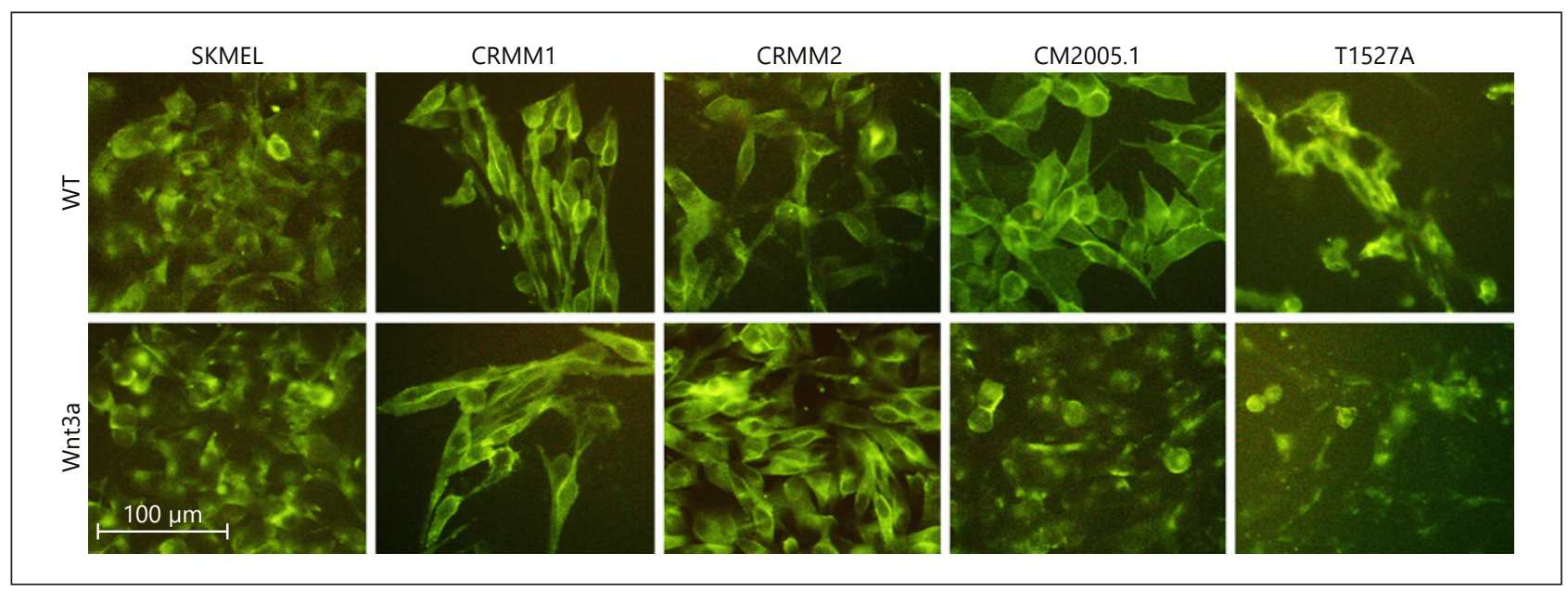

Fig. 6. Wnt3a did not induce nuclear localization of $\beta$-catenin. In the untreated (WT) conjunctival melanoma cell lines and in one skin melanoma cell line (SKMEL), $\beta$-catenin was localized at the cell membrane. Incubation with Wnt3a did not lead to nuclear $\beta$-catenin localization.

lines tested including a cutaneous melanoma, we were not able to identify nuclear $\beta$-catenin translocation and activation with Wnt3a stimulation (Fig. 6).

Stimulation of the Noncanonical Wnt Pathway with Wnt5a Ligand Does Not Increase Motility of the Cell Lines

We finally decided to test whether Wnt5a could induce stimulation of the noncanonical pathway and increase cell motility as previously described $[12,13]$. No significant difference in wound closure was detected between unstimulated and stimulated cell lines (Fig. 7).

\section{Discussion}

The Wnt pathway is not only involved in embryological development but also in the pathogenesis of various tumors, notably in colon adenocarcinoma, where deleterious APC mutations lead to $\beta$-catenin activation [21]. In skin melanoma, both the canonical and the noncanonical Wnt pathway have been implicated in tumorigenesis, with different effects at different stages of tumor progression.

We explored for the first time the status of $\beta$-catenin expression in vitro and in vivo in benign and malignant conjunctival melanocytic proliferations. As demonstrated in some melanoma cell lines [18], we decided to assess if the canonical Wnt pathway was activated in $\mathrm{CM}$, leading to $\beta$-catenin relocalization from the cell membrane to the nucleus. Our results revealed that in benign and malignant conjunctival melanocytic lesions, membranous $\beta$-catenin expression was predominant. In CM, nuclear $\beta$-catenin localization does not appear to be a major event, occurring in only $15 \%$ of the cases. In skin melanoma, variable nuclear $\beta$-catenin was found: absent in one study [19] or present in $5.6 \%(13 / 230)$ [22] to $32 \%$ $(49 / 149)$ [23] of the melanomas. Nuclear $\beta$-catenin expression in skin melanoma has been associated with better survival [23, 24].

Nuclear $\beta$-catenin was found in $16 \%$ of the nevi in our study. In skin nevi, nuclear expression of $\beta$-catenin has been variable, from no detection [18] to $44 \%$ [25] or $83.9 \%$ of the cases [23]. In cutaneous melanoma cell lines, activation of $\beta$-catenin and nuclear localization 


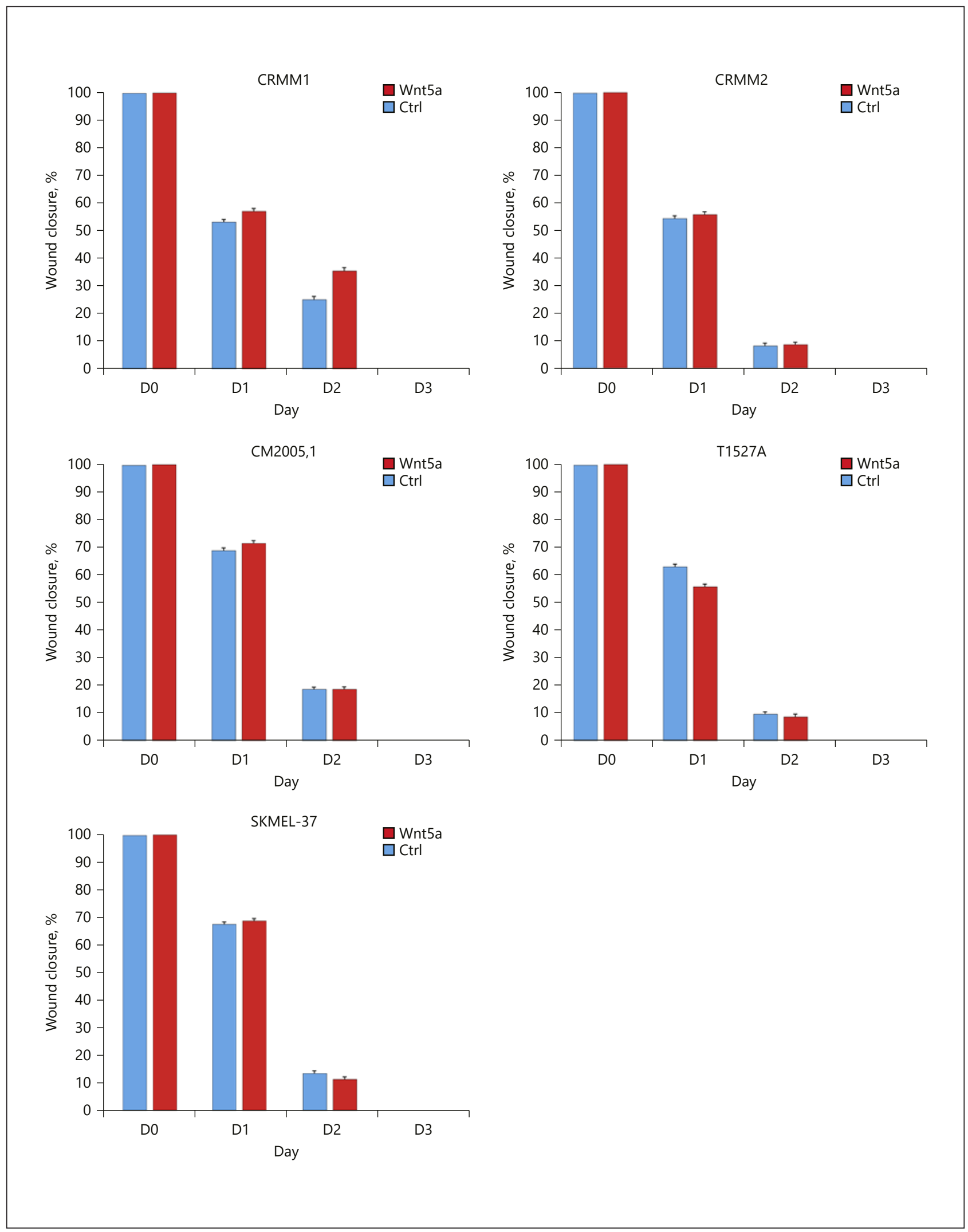

Fig. 7. Wnt5a stimulation did not increase cell motility in conjunctival melanoma. Blue: control group. Red: cell lines stimulated with Wnt5a ligand. 
have been correlated with an upregulation of MITF, decreased proliferation [24], and decreased invasiveness [23]. The various levels of nuclear $\beta$-catenin activation identified in conjunctival and cutaneous nevi could possibly suggest that the differentiation and maintenance of nevi might not only be controlled by $\beta$-catenin.

Interestingly, in a recent study assessing $\beta$-catenin activation in short-term cultures from a cutaneous melanoma [26], two populations of melanoma cells with different phenotypes, invasive abilities, and levels of $\beta$-catenin activation could be identified within the same melanoma: the cells with a high level of $\beta$-catenin activation were less invasive than the cells with a low level of $\beta$-catenin activation. This observation is similar to localized nuclear $\beta$-catenin activation identified in some of our cases of $\mathrm{CM}$ concomitant with $\beta$-catenin membranous expression in other cells within the same tumor, suggesting that, within the same tumor, $\beta$-catenin has different effects depending upon the molecular alterations of the subclones.

As $\beta$-catenin is also involved in cell interactions through binding of E-cadherin [27], we assessed in vitro if cellular confluence had an effect on $\beta$-catenin localization in CM cell lines. As $\beta$-catenin localization was independent of cellular confluence, we further tested if Wnt5a was able to activate $\beta$-catenin and induce nuclear localization. In all our cell lines, Wnt5a did not induce nuclear $\beta$-catenin localization, suggesting that in $\mathrm{CM}$, the signaling observed in subsets of skin melanoma cell lines through the interaction of Wnt5a with the receptor complex Frizzled 4-LRP6 [18] does not occur.

As Wnt5a overexpression in skin melanoma cell lines increased motility [28], we further assessed motility in our CM cell lines using a wound scratch assay. To our surprise, Wnt5a incubation did not increase the speed of wound closure, suggesting that in CM, Wnt5a and probably the noncanonical Wnt pathway do not significantly contribute to cell motility. Alternatively, it has also been suggested that the inhibitory or activating effect of Wnt5a is dependent on the cellular context, notably linked to expression of specific receptor complexes at the cell membrane: upon binding to the receptor complex ROR2 and Fzd2, Wnt5a induces $\beta$-catenin degradation $[29,30]$, which could potentially lead to an increase in invasiveness.

We further assessed if stimulation of the canonical Wnt pathway with Wnt3a could induce nuclear $\beta$-catenin localization in CM cell lines. Surprisingly, Wnt3a induced $\beta$-catenin activation neither in all the CM cell lines tested nor in the skin melanoma cell line evaluated. These findings suggest that in these conjunctival and skin melanoma cell lines, Wnt3a is not able to stimulate the canonical Wnt pathway as previously described [24].

Altogether, our results demonstrate limited activation of $\beta$-catenin in $\mathrm{CM}$, which in our study was not correlated with better outcome. CM motility does not seem to rely on Wnt5a, either through the canonical or the noncanonical Wnt pathway. Our results highlight differences between conjunctival and cutaneous melanoma: activators of the Wnt pathway in skin did not produce the same effect in the conjunctiva. Migration of CM remains to be further evaluated.

\section{Acknowledgements}

The authors would like to thank H. Motta., C. Deweck, and M. Tekaya for their technical support of the study.

\section{Statement of Ethics}

The local Swiss Ethics Committees gave approval for the use of human subject material (protocol 2017-1634). 


\section{Disclosure Statement}

All the authors have no conflict of interest. There was no funding received.

\section{References}

1 McLaughlin CC, Wu XC, Jemal A, Martin HJ, Roche LM, Chen VW. Incidence of noncutaneous melanomas in the U.S. Cancer. 2005 Mar;103(5):1000-7.

2 Shields CL, Demirci H, Karatza E, Shields JA. Clinical survey of 1,643 melanocytic and nonmelanocytic conjunctival tumors. Ophthalmology. 2004 Sep;111(9):1747-54.

3 Rivolta C, Royer-Bertrand B, Rimoldi D, Schalenbourg A, Zografos L, Leyvraz S, et al. UV light signature in conjunctival melanoma; not only skin should be protected from solar radiation. J Hum Genet. 2016 Apr;61(4): 361-2.

4 Shields JA, Shields CL, Mashayekhi A, Marr BP, Benavides R, Thangappan A, et al. Primary acquired melanosis of the conjunctiva: risks for progression to melanoma in 311 eyes. The 2006 Lorenz E. Zimmerman lecture. Ophthalmology. 2008 Mar;115(3):511-519.e2.

5 Grossniklaus HE, Eberhart CG, Kivela TT. WHO classification tumors of the eye. 4th ed. IARC; 2018. vol. 12.

6 Griewank KG, Westekemper H, Murali R, Mach M, Schilling B, Wiesner T, et al. Conjunctival melanomas harbor BRAF and NRAS mutations and copy number changes similar to cutaneous and mucosal melanomas. Clin Cancer Res. 2013 Jun;19(12):3143-52.

7 Scholz SL, Cosgarea I, Süßkind D, Murali R, Möller I, Reis H, et al. NF1 mutations in conjunctival melanoma. Br J Cancer. 2018 May;118(9):1243-7.

8 O'Connell MP, Weeraratna AT. Hear the Wnt Ror: how melanoma cells adjust to changes in Wnt. Pigment Cell Melanoma Res. 2009 Dec;22(6):724-39.

9 Larue L, Delmas V. The WNT/Beta-catenin pathway in melanoma. Front Biosci. 2006 Jan;11(1):733-42.

10 Dunn KJ, Brady M, Ochsenbauer-Jambor C, Snyder S, Incao A, Pavan WJ. WNT1 and WNT3a promote expansion of melanocytes through distinct modes of action. Pigment Cell Res. 2005 Jun;18(3):167-80.

11 Larue L, Luciani F, Kumasaka M, Champeval D, Demirkan N, Bonaventure J, et al. Bypassing melanocyte senescence by beta-catenin: a novel way to promote melanoma. Pathol Biol (Paris). 2009 Nov-Dec;57(7-8):543-7.

12 Dissanayake SK, Wade M, Johnson CE, O'Connell MP, Leotlela PD, French AD, et al. The Wnt5A/protein kinase $\mathrm{C}$ pathway mediates motility in melanoma cells via the inhibition of metastasis suppressors and initiation of an epithelial to mesenchymal transition. J Biol Chem. 2007 Jun;282(23):17259-71.

13 O'Connell MP, Fiori JL, Baugher KM, Indig FE, French AD, Camilli TC, et al. Wnt5A activates the calpainmediated cleavage of filamin A. J Invest Dermatol. 2009 Jul;129(7):1782-9.

14 O'Connell MP, French AD, Leotlela PD, Weeraratna AT. Assaying Wnt5A-Mediated Invasion in Melanoma Cells. In: Vincan E, editor. Wht Signaling [Internet]. Totowa (NJ): Humana Press; 2008. p. 243-53. [Cited 2017 Aug 13]. Available from: http://link.springer.com/10.1007/978-1-59745-249-6_19.

15 Widlund HR, Horstmann MA, Price ER, Cui J, Lessnick SL, Wu M, et al. $\beta$-Catenin-induced melanoma growth requires the downstream target microphthalmia-associated transcription factor. J Cell Biol. 2002 Sep;158(6): 1079-87.

16 Goodall J, Martinozzi S, Dexter TJ, Champeval D, Carreira S, Larue L, et al. Brn-2 expression controls melanoma proliferation and is directly regulated by beta-catenin. Mol Cell Biol. 2004 Apr;24(7):2915-22.

17 Delmas V, Beermann F, Martinozzi S, Carreira S, Ackermann J, Kumasaka M, et al. Beta-catenin induces immortalization of melanocytes by suppressing p16INK4a expression and cooperates with N-Ras in melanoma development. Genes Dev. 2007 Nov;21(22):2923-35.

18 Grossmann AH, Yoo JH, Clancy J, Sorensen LK, Sedgwick A, Tong Z, et al. The small GTPase ARF6 stimulates $\beta$-catenin transcriptional activity during WNT5A-mediated melanoma invasion and metastasis. Sci Signal. 2013 Mar;6(265):ra14.

19 Rosner K, Mehregan DR, Kirou E, Abrams J, Kim S, Campbell M, et al. Melanoma Development and Progression Are Associated with Rad6 Upregulation and $\beta$-Catenin Relocation to the Cell Membrane. J Skin Cancer. 2014; 2014:439205

20 Jonkman JE, Cathcart JA, Xu F, Bartolini ME, Amon JE, Stevens KM, et al. An introduction to the wound healing assay using live-cell microscopy. Cell Adhes Migr. 2014;8(5):440-51.

21 Morin PJ, Sparks AB, Korinek V, Barker N, Clevers H, Vogelstein B, et al. Activation of beta-catenin-Tcf signaling in colon cancer by mutations in beta-catenin or APC. Science. 1997 Mar;275(5307):1787-90.

22 Maelandsmo GM, Holm R, Nesland JM, Fodstad Ø, Flørenes VA. Reduced $\beta$-catenin expression in the cytoplasm of advanced-stage superficial spreading malignant melanoma. Clin Cancer Res. 2003 Aug;9(9):3383-8.

23 Bachmann IM, Straume O, Puntervoll HE, Kalvenes MB, Akslen LA. Importance of P-cadherin, beta-catenin, and Wnt5a/frizzled for progression of melanocytic tumors and prognosis in cutaneous melanoma. Clin Cancer Res. 2005 Dec;11(24 Pt 1):8606-14. 
24 Chien AJ, Moore EC, Lonsdorf AS, Kulikauskas RM, Rothberg BG, Berger AJ, et al. Activated Wnt/beta-catenin signaling in melanoma is associated with decreased proliferation in patient tumors and a murine melanoma model. Proc Natl Acad Sci USA. 2009 Jan;106(4):1193-8.

25 Kageshita T, Hamby CV, Ishihara T, Matsumoto K, Saida T, Ono T. Loss of beta-catenin expression associated with disease progression in malignant melanoma. Br J Dermatol. 2001 Aug;145(2):210-6.

26 Kovacs D, Migliano E, Muscardin L, Silipo V, Catricalà C, Picardo M, et al. The role of Wnt/ $\beta$-catenin signaling pathway in melanoma epithelial-to-mesenchymal-like switching: evidences from patients-derived cell lines. Oncotarget. 2016 Jul;7(28):43295-314.

27 Ozawa M, Baribault H, Kemler R. The cytoplasmic domain of the cell adhesion molecule uvomorulin associates with three independent proteins structurally related in different species. EMBO J. 1989 Jun;8(6):1711-7.

28 Weeraratna AT, Jiang Y, Hostetter G, Rosenblatt K, Duray P, Bittner M, et al. Wnt5a signaling directly affects cell motility and invasion of metastatic melanoma. Cancer Cell. 2002 Apr;1(3):279-88.

29 Mikels AJ, Nusse R. Purified Wnt5a protein activates or inhibits beta-catenin-TCF signaling depending on receptor context. PLoS Biol. 2006 Apr;4(4):e115.

30 Webster MR, Weeraratna AT. A Wnt-er migration: the confusing role of $\beta$-catenin in melanoma metastasis. Sci Signal. 2013 Mar;6(268):pe11.

31 MacDonald BT, Tamai K, He X. Wnt/ $\beta$-catenin signaling: components, mechanisms, and diseases. Dev Cell. 2009 Jul;17(1):9-26. 